\title{
Rancangan Pop-up Book Freight Forwarding Sebagai Media Pembelajaran Mandiri
}

\author{
Dodi Permadi' (), M Ilham Ma'ruf(2) Jatiana Ayu Wijayanti ${ }^{3)}$ \\ 1)Program Studi D4 Logistik Bisnis, Politeknik Pos Indonesia \\ email: dodipermadi@poltekpos.ac.id \\ ${ }_{2}$ Program Studi D4 Logistik Bisnis, Politeknik Pos Indonesia \\ email: ilhammaruf@gmail.com \\ 3)Program Studi D4 Logistik Bisnis, Politeknik Pos Indonesia \\ email: jatianaayu@gmail.com
}

\begin{abstract}
ABSTRAK
Pada penelitian ini dilakukan proses perancangan pembelajaran mandiri freight forwarding melalui media pop up book, dengan tujuan memberikan kemudahan sehingga tampil secara visual yang menarik dan mudah untuk dipahami. Tahapan perancangan ini menggunakan pendekatan prototype dengan terlebih dahulu melalukan diskusi dengan perwakilan mahasiswa tentang kebutuhannya.Data yang diperoleh berdasarkan referensi akan diolah dan diterapkan dalam pembuatan pop-up book. Metode pelaksanaan dalam pembuatan terdiri dari 3 tahapan yang meliputi: penyusunan konsep, pembuatan desain 3D, dan pembuatan prototype, pengujian dan evaluasi. Hasil perancangan berupa protitype dan dilakukan verifi-kasi melalui penyebaran angket kuesioner terhadap responden dari Program Studi Diploma IV Logistik Bisnis Politeknik Pos Indonesia dengan hasil respon yang positif. Adanya media pembelajaran pop-up book freight forwarding dapat membantu mahasiswa dalam meningkatkan pemahaman mengenai kegiatan dan alur proses freight forwarding. Dari gambar dan visualisasi media tersebut membuat mahasiswa tertarik untuk belajar dan memudahkan mereka dalam mengingat setiap proses dan disertai dengan dokumen pendukung dalam setiap prosesnya tentu membuat mahasiswa lebih mudah belajar freight forwarding dengan cepat.
\end{abstract}

Kata kunci : Freight forwarding, pop up book, prototype

\section{PENDAHULUAN}

Freight forwarder adalah badan usaha yang bertujuan untuk memberikan jasa pelayanan/pengurusan atas seluruh kegiatan yang diperlukan bagi terlaksananya pengiriman, pengangkutan dan penerimaan barang dengan menggunakan multimodal transport baik melalui darat, laut atau udara (Suyono, 2005). Freight forwarding adalah Usaha Berbadan Hukum Indonesia, yang ditujukan untuk mewakili kepentingan Pemilik Barang, untuk mengurus semua kegiatan yang diperlukan bagi terlaksananya pengiriman dan penerimaan barang melalui transportasi darat, laut dan udara yang dapat mencakup kegiatan penerimaan, penyimpanan, sortasi, pengepakan, penandaan pengukuran, penimbangan, pengurusan penyelesaian dokumen, penerbitan dokumen angkutan, klaim asuransi, atas pengiriman barang serta penyelesaian tagihan dan biaya-biaya lainnya berkenan dengan pengiriman barang-barang tersebut sampai dengan diterimanya barang oleh yang berhak menerimanya (PER-178/PJ/2006 DISHUB). Belajar freight forwarding tidak hanya sebatas membaca materi, tetapi mengingat dan memahami apa yang dibaca, sehingga pemahaman fakta, konsep, prinsip freight forwarding dan kemampuan proses ilmiah mahasiswa maupun masyarakat umum dapat dikembangkan.
Proses pembelajaran materi freight forwarding yang dilakukan oleh seorang dosen dan mahasiswa pada saat ini, kebanyakan masih menggunakan buku maupun modul bahasa asing yang diterjemahkan kedalam Bahasa Indonesia yang tersedia di berbagai perpustakan. Modul freight forwarding yang tersedia di perpustakaan masih sangatlah sedikit. Hal ini menunjukkan keterbatasan materi pembelajaran freight forwarding.

Mempelajari materi freight forwarding melalui modul memanglah menarik bagi sebagian dosen maupun mahasiswa yang memang tertarik dengan freight forwarding karena modul bisa dibaca dimanapun, kapanpun, dan ketika lupa informasi tersebut masih tetap ada di modul tidak akan hilang. Namun bagi sebagian dosen dan mahasiswa yang tidak tertarik dengan freight forwarding menganggap bahwa mempelajari freight forwarding merupakan suatu kegiatan yang membosankan, karena sampai sekarang pada saat mempelajari freight forwarding pasti akan disodorkan sebuah modul atau buku yang tebal, penuh tulisan, serta kurang adanya visual yang menarik.

Sekilas pop-up book hampir sama dengan origami dimana kedua seni ini mempergunakan teknik melipat kertas (Nancy dan Rondha, 2012). Pop- up book dianggap mempunyai daya tarik tersendiri bagi pembacanya dengan menyajikan visualisasi dengan 
bentuk-bentuk yang dibuat dengan alur cerita, dengan melipat, memiliki bagian yang dapat bergerak atau memiliki unsur 3 dimensi, dengan demikian sama hal nya dengan metode menghafal teknik loci atau sering dikenal istilah "Istana memori" dari berbagai riset penelitian terbukti sangatlah efektif dalam pembelajaran yang memerlukan hafalan sekaligus pemahanan.

\section{STUDI LITERATUR}

Freight forwarding adalah badan usaha yang bertujuan untuk memberikan jasa pelayanan/pengurusan atas seluruh kegiatan yang diperlukan bagi terlaksananya pengiriman, pengangkutan dan penerimaan barang dengan menggunakan multimoda transportasi baik melalui darat, laut, dan atau udara (Suyono, 2007).

Freight forwarding adalah badan usaha yang bergerak dalam bidang jasa pengurusan dokumen dan transportasi, dimana peran utamanya adalah sebagai "pemberi jasa" antara shipper (pengirim/eksportir) dan consignee (penerima/importir) atau airline (angkutan udara) dan shipping line (angkutan laut) (Susilo,2008).

\subsection{Dokumen Freight Forwarding}

Peranan dokumen dalam kegiatan freight forwarding sangatlah penting, karena tergantung sejauh mana dokumen yang diserahkan kepada pihak yang dituju. Secara umum dokumen dalam kegiatan freight forwarding dibagi dalam 3 bagian besar yaitu :

\subsubsection{Dokumen Utama}

Dokumen utama ialah dokumen wajib dalam kegiatan ekspor impor, arttinya dokumen ini harus selalu ada dalam kegiatan freight forwarding. Secara garis besar dokumen utama dalam kegiatan freight forwarding yaitu sebagai berikut:

1. Wesel atau Draft atau Bill of Exchange

2. $B / L$ atau Bill of Lading (pengiriman laut), Air Waybil (pengiriman udara)

3. Invoice

4. Packing List

5. Polis Asuransi

\subsubsection{Dokumen Pendukung}

Dokumen pendukung ialah dokumen yang berfungsi sebagai pendukung dokumen utama, artinya dokumen ini dapat berfungsi sebagai pendukung untuk memastikan bahwa barang yang dikirim dalam kualitas dan kuantitas yang sesuai dengan permintaan pembeli. Dokumen pendukung meliputi:

1. $\mathrm{COO}$ atau Certificate of Origin
2. Certificate of Inspection

3. Quarantine Certificate

4. Certificate of Fumigation

\subsubsection{Dokumen Tambahan}

Dokumen tambahan ialah dokumen yang tidak selalu diminta dalam kegiatan freight forwarding, dokumen ini meliputi:

1. COA atau Certificate of Analysis atau Certificate yang menyatakan analisis kandungan unsur kimia dan zat pembangun produk tersebut.

2. MSDS ( Material Safety Data Sheet )

3. Brochure

4. Leaflet

5. Weight Note/ Nota Timbangan

6. Measurement List/ Daftar Kubikasi

7. Certificate of Quality

\subsection{Pengertian Pop-Up Book}

Media pop-up book merupakan salah satu media yang dapat digunakan sebagai saluran penyampaian materi dari dosen kepada mahasiswa. Pop-Up Book adalah sebuah buku yang memiliki bagian yang dapat bergerak atau memiliki unsur tiga dimensi serta memberikan visualisasi cerita yang lebih menarik, mulai dari tampilan gambar yang dapat bergerak ketika halamannya dibuka (Dzuanda, 2011). Pop-up book adalah sebuah buku yang menampilkan potensi untuk bergerak dan interaksinya melalui penggunaan kertas sebagai bahan lipatan, gulungan, bentuk, roda atau putarannya. Hal ini sesuai dengan pernyataan yang dikemukakan oleh Sylvia dan Hariani (2015: 1197), yang berbunyi, "pop up book is a book that offers the potential formotion and interaction through the use of paper mechanisms such as folds, scrolls, slides, tabs or wheels". Pop- up book adalah sebuah buku cerita bergambar dengan gambar yang lucu atau yang bentuknya menarik karena dapat bergerak ketika halamannya dibuka. Pengertian lain menurut Montanaro (2009) pop-up book merupakan sebuah buku yang memiliki bagian yang dapat bergerak atau memiliki unsur 3 dimensi. Sedangkan menurut Joko Muktiono (2003), pop-up book adalah sebuah buku yang memiliki tampilan gambar yang bisa ditegakkan serta membentuk obyek-obyek yang indah dan dapat bergerak atau memberi efek yang menakjubkan. Menurut Dzuanda (2011), jenis-jenis pop-up book ada bermacam-macam, beberapa diantaranya adalah transformations pop-up, tunnel pop-up books, Volvelles pop-up, Movable pop-up, Pull-tabs dan Pop-outs.

Berdasarkan uraian diatas, dapat disimpulkan pop-up book adalah buku yang memiliki bagian yang dapat bergerak atau berunsur tiga dimensi. Pop-up book memberikan visualisasi cerita yang lebih menarik. Buku ini 
juga memberikan kejutan-kejutan dalam setiap halamannya yang dapat mengundang ketakjuban ketika halamannya dibuka, disamping itu pop-up book memiliki tampilan gambar yang indah dan dapat ditegakkan. Sehingga media pop-up book sangatlah cocok digunakan sebagai alat peraga. Selain itu, proses pembelajaran dengan menggunakan media pop-up book akan jauh lebih menyenangkan.

\section{METODOLOGI}

Metode yang digunakan dalam kegiatan ini adalah dengan membuat kerangka kerja, dimana kerangka kerja tersebut akan menjelaskan secara garis besar urutan yang akan dilaksanakan.

\subsection{Tahap Penyusunan Konsep}

Penyusunan konsep ini adalah membuat rancangan awal desain media pop-up book freight forwarding berdasarkan data-data yang telah diperoleh dari referensi berupa ocean freight dan air freight yang dipelajari dalam mata kuliah Logistik Bisnis. Ocean freight dan air freight saat ini sangat dibutuhkan oleh mahasiswa maupun masyarakat perusahaan untuk kegiatan bisnis ekspor dan impor yang melibatkan banyak pihak lain, sehingga perlu adanya media untuk membantu dan memudahkan dalam proses pembelajaran yang dapat meningkatkan pemahaman dan daya ingat dengan adanya visualisasi. Data sekunder yang didapatkan yaitu dari data perusahaan yang bergerak di bidang Freight Forwarding. Desain pop-up book berukuran A3, pemilihan ukuran ini agar ukurannya tidak terlalu besar dan terlalu kecil bagi pembaca yang digunakan sebagai media pembelajaran dengan konsep buku 3 dimensi.

\subsection{Tahap Desain 3D}

Pembuatan desain pop-up book dari rancangan konsep yang telah dibuat dengan menggunakan software correldraw sehingga didapatkan desain 3 dimensi untuk membuat pop-up book freight forwarding.

\subsection{Tahap Pembuatan Prototype, Pengujian dan Evaluasi}

Pembuatan prototype sesuai dengan konsep dan desain yang telah didapatkan sebelumnya dengan menggunakan alat perkakas dan bahan utama: (i) Cutter, (ii)lem, (iii)Penggaris, (iv)kertas ivory, (v) hard cover, dan (vi)papan cutting board. Hasil dari pembuatan prototype akan dilakukan pengujian tingkat keandalan dan kenyamanan dengan mengambil sampel sebanyak 20-30 mahasiswa untuk menguji coba prototype tersebut. Pengujian ini menggunakan Angket yang diberikan pada mahasiswa untuk mengetahui respon mahasiswa terhadap penerapan media pop-up book freight forwarding

\section{HASIL}

Hasil tampilan dari produk ini dapat dilihat pada gambar 4.11 yaitu pop-up book freight forwarding yang dibuat sesuai dengan desain yang telah dirancang di aplikasi desain correldraw. Dalam pembuatan buku 3 dimensi yang kami sebut dengan pop-up book freight forwarding ini kami menggunakan ukuran A3.

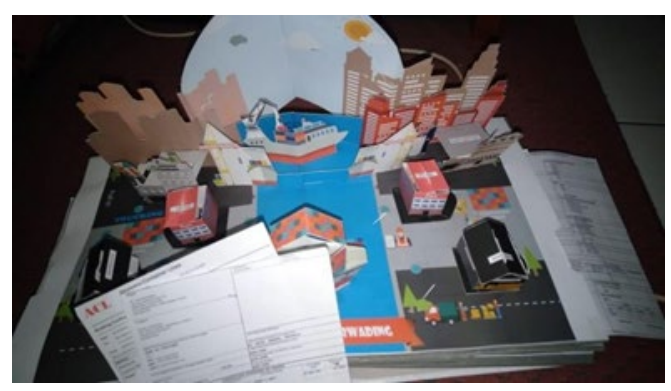

Gambar 1 Pop-Up Book Freight Forwarding 1

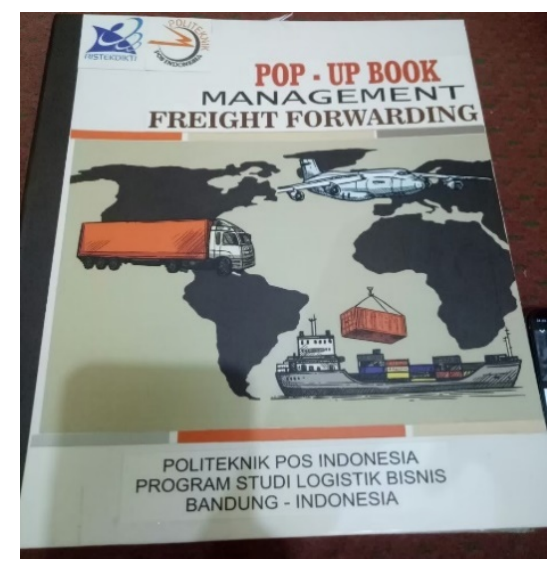

Gambar 2 Cover Pop-Up Book Freight Forwarding

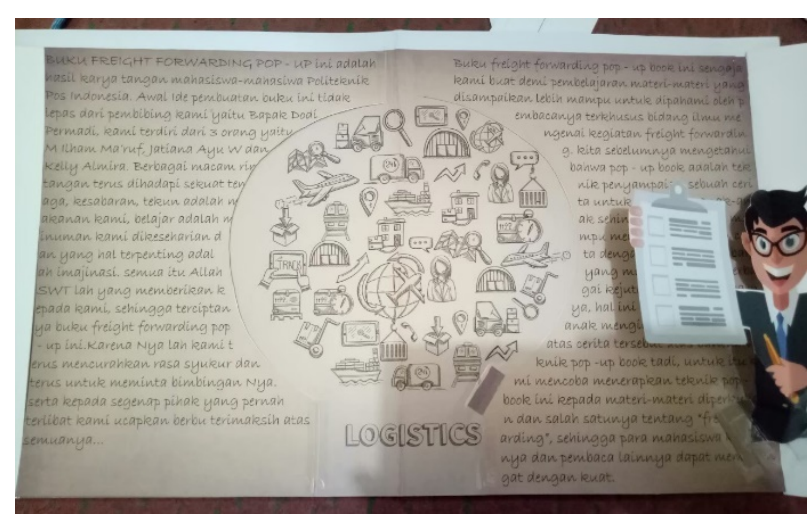

Gambar 3 Hal 1 Pop-Up Book Freight Forwarding 

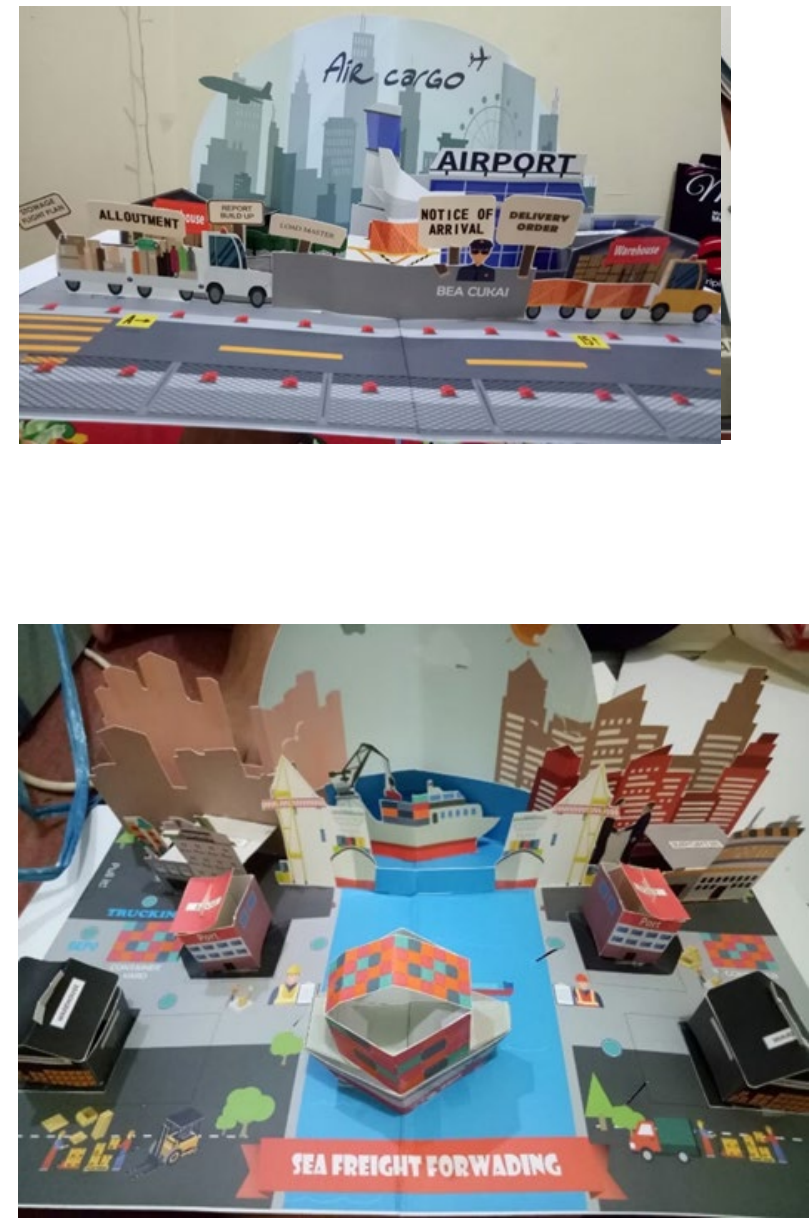

Gambar 4 Hal 2 Pop-Up Book bagian Sea Freight Forwarding

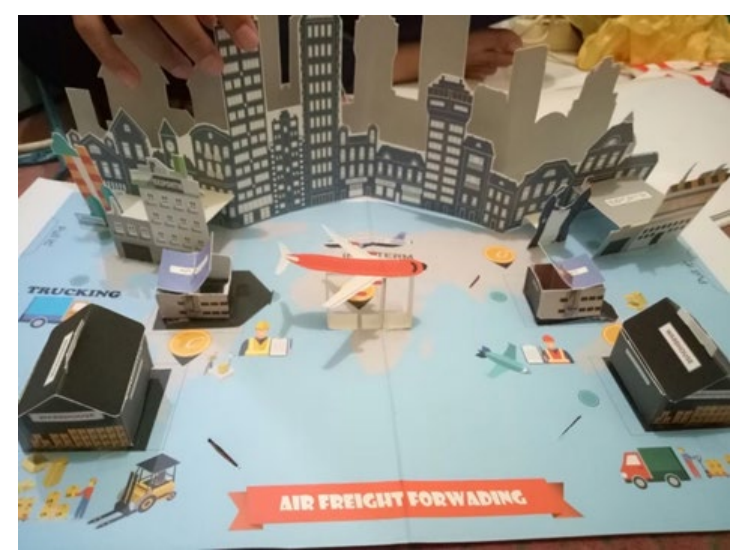

Gambar 5 Hal 3 Pop-Up Book bagian Air Freight
Gambar 6 Hal 4 Pop-Up Book bagian Pelabuhan

Gambar 7 Hal 5 Pop-Up Book bagian Bandara

\subsection{Uji Respon}

Kami melakukan uji coba untuk mengetahui tingkat kehandalan dan kenyamanan pada produk dengan mengambil sampel sebanyak 34 responden melalui kuesioner melalui google drive dan didapatlah hasil sebagai berikut:

Apakah anda sudah mengetahui Pop up book freight forwarding? 34 responses

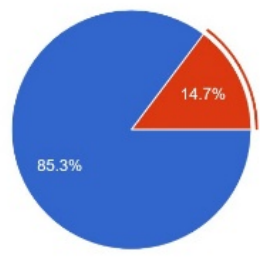

$$
\text { Ya }
$$

Gambar 8 Grafik Pengetahuan pop up book

Apakah pop up book tersebut membantu anda dalam proses pembelajaran materi freight forwarding? 33 responses

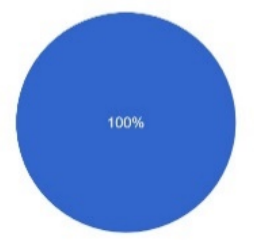

Ya

Gambar 9 Grafik Kegunaan pop up book

Apakah pop up book freight forwarding menarik? 34 responses

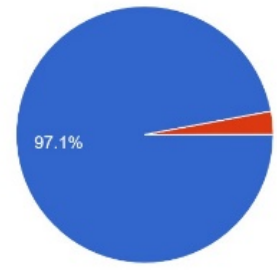

Ya - Tidak

Gambar 10 Grafik Ketertarikan responden 


\section{KESIMPULAN}

Hasil penelitian ini memberikan alternatif.pembelajaran melalui pop up book, khususnya mata kuliah freight forwarding. Rancangan masih berupa prototype yang mengharuskan pengembangan lebih lanjut. Prototype ini bisa dikembangkan melalui simulasi dengan komputer yang lebih rinci.

\section{REFERENSI}

[1] Dzuanda. 2011. Design Pop-Up Child Book Puppet Figures Series? Gatotkaca?.Jurnal Library ITS Undergraduate, (Online), (http:// library.its.undergraduate.ac.id). Diakses 15 Januari 2018

[2] Lismayanti, M. 2016. Pengembangan Buku Pop-Up Sebagai Media Pembelajaran Pada Materi Crustacea Untuk SMA Kelas X. FKIP Universitas Jambi, Jambi.

[3] Montanaro, Ann. (2009). A Concise History of Popup and Movable Books. http://www.libraries.rutgers.edu/rul/libs/scua/mont anar/p-intro.htm). (diakses tanggal 15 Juni 2014)

[4] Mutikno, JD, 2003. Aku cinta buku (menumbuhkan minat baca pada anak (Jakarta, Elex Media Komputindo)

[5] Nancy, L. B., \& Rhonda, H. T. 2012. Pop-Up Books : A guide for Teachers and Librarians. California: Santa Barbara.

[6] Setyaningsih, Ervita I. 2009. Peranan Freight Forwarder Dalam Menunjang Aktivitas Ekspor Pada Pt. Arindo Jaya Mandiri Semarang. Universitas Negeri Semarang, Solo.

[7] Susilo, Andi, 2008 Buku Pintar Ekspor-Impor, Trans Media Pustaka

[8] Suyono,R.P.,(2005).Shipping:Pengangkutan Intermodal Ekspor Impor Melalui Laut, Penerbit PPM

[9] Sylvia, I. N. \& Hariani, N. 2015. "Pengaruh Penggunaan Media Pop-Up Book terhadap Keterampilan Menulis Narasi Siswa Sekolah Dasar". Jurnal Pendidikan Guru Sekolah Dasar, 3(2): 1196-1205 